\title{
Transgenic peanut plants obtained by particle bombardment via somatic embryogenesis regeneration system
}

\author{
DENG Xiang Yang, Zhi Ming WEI*, Hai Long AN
}

Institute of Plant Physiology and Ecology, Shanghai Institutes for Biological Sciences, Chinese Academy Sciences, Shanghai 200032, China

\begin{abstract}
After pre-culture and treatment of osmosis, cotyledons of immature peanut (Arachis hypogaea L.) zygotic embryos were transformed via particle bombardment with a plasmid containing a chimeric hph gene conferring resistance to hygromycin and a chimeric intron-gus gene. Selection for hygromycin resistant calluses and somatic embryos was initiated at 10th d post-bombardment on medium containing 10-25 mg/L hygromycin. Under continuous selection, hygromycin resistant plantlets were regenerated from somatic embryos and were recovered from nearly $1.6 \%$ of the bombarded cotyledons. The presence and integration of foreign DNA in regenerated hygromycin resistant plants was confirmed by PCR (polymerase chain reaction) for the intron-gus gene and by Southern hybridization of the hph gene. GUS enzyme activity was detected in leaflets from transgenic plants but not from control, non-transformed plants. The production of transgenic plants are mainly based on a newly improved somatic embryogenesis regeneration system developed by us.
\end{abstract}

Key words: Peanut (Arachis hypogaea), somatic embryo, hygromycin resistance, particle bombardment.

\section{INTRODUCTION}

Arachis hypogaea L., Peanut or groundnut, is an important commercial crop worldwide. It provides an excellent source of protein and other nutrients. Its production and quality can be severely impacted under stressful growing conditions such as climate factors, pests and diseases. Genetic engineering provides a prospective way to reduce certain problems by transferring individual genes for pest resistance or other traits into elite germplasm of a cultivated species. Transgenic peanut plants have been produced by particle bombardment[1] and via Agrobacterium-mediated transformation[2]. Microprojectile bombardment uses high velocity particles to penetrate cell walls and to deliver DNA into intact plant cells. This circumvents the hostrange limitations of Agrobacterium, and the difficulties associated with plant regeneration from protoplasts and appeared to be the method of choice to transform many legumes to avoid the possible prob-

\footnotetext{
* Corresponding authors: Zhi Ming WEI, zmwei@iris.sipp.ac.cn Received July-4-2000 Revised April-28-2001 Accepted April29-2001
}

lems associated with genotype or tissue specificity of Agrobacterium strain.

There are a lot of reports about regeneration systems by somatic embryogenesis induced by $2,4-$ D using different kinds of explants, such as cotyledons[3], leaflets[4], axes[5],[6]. However, as far as we know, there are no reports on the production of transgenic plants using these regeneration systems due to some unknown reasons. Recently, we developed a newly improved and more efficient regeneration system via somatic embryogenesis induced by 2, 4-D using cotyledons of immature zygotic embryos through doing multiple factorial experiments involving light density, 2, 4-D concentration, cotyledon length and inoculation methods[7]. On the basis of this work, we designed the present study to developed a particle bombardment transformation system for peanut and have obtained transgenic peanut plants.

\section{MATERIAL AND METHODS}

Plant materials, inoculation and pre-experiments 
Peanut plants (cultivars Luhua 9 and YueYou 116) were grown in the greenhouse in pots containing a 1:1 (v/v) mixture of sand and field soil. Immature pods were harvested $30 \sim 50 \mathrm{~d}$ after pollination. Pods were scrubbed in a mild detergent solution and rinsed in $70 \%(\mathrm{v} / \mathrm{v})$ ethanol for $4 \mathrm{~min}$, then sterilized by $0.1 \% \mathrm{HgCl}$ for $15 \mathrm{~min}$ followed by sterilized water. Immature seeds were removed from the surface-cleaned pods, then the immature embryos were removed from the seed, and embryos were measured in $3 \sim 14 \mathrm{~mm}$ above millimeter scale in sterile condition. The shoot-root axes of embryos were divided into equal halves along long axis to get the whole cotyledons. With the abaxial surfaces of cotyledons in contact with the medium, two cotyledons in the length of $3 \sim 6 \mathrm{~mm}, 7 \sim 10 \mathrm{~mm}, 11 \sim 14$ $\mathrm{mm}$ were respectively cultured on a $9 \mathrm{~cm}$ Perish dish containing $30 \mathrm{ml}$ induction medium with 10, 20, $40 \mathrm{mg} / \mathrm{L} \mathrm{2,} \mathrm{4-D} \mathrm{(designated}$ as D10, D20, D40)[7]. The basic composition of induction media was Murashige and Skoog (MS) salts and B5 vitamins, 0.7\% agar, 3\% sucrose (D10, D20) or 6\% sucrose (D40). The $\mathrm{pH}$ was adjusted to 5.8 (D10, D20) or 6.3 (D40) prior to autoclaving. All cultures were grown in the dark at $25-28^{\circ} \mathrm{C}$.

In pre-experiment No. 1, we tested the effect of pre-cul- ture and osmosis treatment on transformation. After $1 \sim 10 \mathrm{~d}$ preculture in induction medium, part of $3 \mathrm{~d}$ pre-cultured cotyledons were treated for $3 \mathrm{~h}$ by osmosis medium-the induction medium containing $0.4 \mathrm{M}$ mannitol. Then all cotyledons were used for particle bombardment. After being cultured in induction medium for $10 \mathrm{~d}$ post-bombardment, the cotyledons were used for GUS analysis and GUS blue spots were counted under microscope. In pre-experiment No. 2, cotyledons were cultured in induction medium containing different concentrations of hygromycin. The initiated somatic embryos and embryogenic calluses were counted after $30 \mathrm{~d}$ post-initiation.

\section{Plasmid constructs and microprojectile bom- bardment}

Plasmid CAMBIA-1301 (provided by the Lab of Prof. HONG Meng Ming) was used for bombardment. The pCAMBIA-1301 contains a $\beta$-Glucuronidase uidA, gus gene with an intron and a hygromycin phosphotransferase (hph ) gene, both under control of the CaMV 35S promoter. Plasmid DNA was isolated from recombinant E. Coli by the alkaline lysis method and was purified with $13 \%$ PEG solution[8]. Particles coated with plasmid[1] were bombarded into cotyledons using a PDS 1000/helium-driven apparatus (Bio-Rad, CA, USA). Each bombardment delivered approximately $1 \mu \mathrm{g}$ DNA and $300 \mu \mathrm{g}$ gold particle $1.0 \mathrm{~mm}$ in diameter. Micro-carriers coated by DNA were accelerated by helium using $1300 \mathrm{psi}(9.0 \mathrm{MPa}$ ) rupture discs in 28 inch $\mathrm{Hg}$ (96. $4 \mathrm{MPa}$ ) vacuum chamber. Each plate contained $9 \sim 15$ cotyledons within an area in about $2.5 \mathrm{~cm}$ diameter and were bombarded twice. The sample platform was positioned $5 \mathrm{~cm}$ below the launch assembly in all experiment.

\section{Pre-culture, osmosis treatment and the regen- eration of hygromycin-resistant plants}

In transformation experiments, after $1 \sim 5 \mathrm{~d}$ pre-culture in induction medium, cotyledons were transferred to induction medium containing $0.4 \mathrm{M}$ mannitol for $3 \mathrm{~h}$ before bombardment. After bombardment, cotyledons were kept in the same medium for $12 \sim 18 \mathrm{~h}$ and then transferred into induction medium and cultured for about $10 \mathrm{~d}$. During the selection, cotyledons of 3 $6 \mathrm{~mm}, 7 \sim 10 \mathrm{~mm}, 11 \sim 14 \mathrm{~mm}$ were respectively transferred to solid selection mediums of D10, D20, D40 containing $10 \sim 20$ $\mathrm{mg} / \mathrm{L}$ hygromycin. After $14 \mathrm{~d}$, cotyledons were transferred to fresh selection media for another $14 \mathrm{~d}$. Surviving cotyledons with newly formed embryogenic calluses were transferred into liquid selection medium D10 containing $20 \mathrm{mg} / \mathrm{L}$ hygromycin for weekly subculture. Embryogenic calluses from approximately 3-4 cotyledons were transferred into a $125 \mathrm{ml}$ Erlenmeyer flask containing $25 \mathrm{ml}$ liquid selection medium on the shaker (120 rpm) in darkness. After $6 \mathrm{w}$, hygromycin-resistant embryogenic calluses were selected and cultured in solid selection medium D20 containing $20 \mathrm{mg} / \mathrm{L}$ hygromycin at 25 -d intervals. Hygromycin-resistant somatic embryos, obtained during selection culture, were transferred to B5 medium containing 6\% maltose, $0.5 \%$ active carbon and $15 \mathrm{mg} / \mathrm{L}$ hygromycin. After $2 \mathrm{w}$, the somatic embryos were then transferred into B5 medium with $0.5 \mathrm{mg} / \mathrm{L} \mathrm{NAA}, 0.15 \mathrm{mg} / \mathrm{L} \mathrm{BA}, 0.15 \mathrm{mg} / \mathrm{L} \mathrm{KT}, 0.15 \mathrm{mg} / \mathrm{L} \mathrm{ZT}$, $25 \mu \mathrm{M} \mathrm{AgNO}_{3}$ and $15 \mu \mathrm{g} / \mathrm{L}$ hygromycin until the roots and shoots could be seen by naked eye. Shoots elongated under light (average of $15 \mu \mathrm{M} \mathrm{m}^{-2} \mathrm{~S}^{-1}$ from cool white fluorescent lamps for a 16 -h per d) at $28 \mathrm{oC}$ on the half strength MS medium with $2 \%$ sucrose, $0.1 \mathrm{mg} / \mathrm{L}$ indole butyric acid (IBA), $0.1 \mathrm{mg} / \mathrm{L}$ gibberellic acid (GA3), and $15 \mathrm{mg} / \mathrm{L}$ hygromycin. Resistant regenerated plantlets with roots were transferred into pots containing sand and soil in greenhouse.

\section{GUS assay}

Expression of gus was confirmed by the GUS assay acco-ding to Jefferson (1987)[9]. The assay solution contained $0.5 \mathrm{mM}$ potassium ferricyanide, $0.5 \mathrm{mM}$ potassium ferrocyanide, $0.3 \%$ (v/v) Triton X-100, and $1 \mathrm{mg} / \mathrm{ml} 5$ - $\beta$ romo-4-chloro-3-indolyl b$\mathrm{D}$-glucuronide (X-gluc) in $50 \mathrm{mM}$ phosphate buffer, $\mathrm{pH}$ 7.0. Leaflets randomly collected from hygromycin-resistant plants and cotyledons in pre-experiments were placed in a micro-centrifuge tube containing about $0.8 \mathrm{ml}$ staining solution. The tubes were incubated for $24 \mathrm{~h}$ at $37^{\circ} \mathrm{C}$. The sample buffer was discarded and materials were washed by $95 \%(\mathrm{v} / \mathrm{v})$ ethanol.

\section{DNA analysis}

Small amount DNA was extracted from some leaflets of regenerated plants[10]. The presence of the gus gene was detected by PCR using the following 2 primers: the forward (5' GGGATCCATCGCAGCGTAATG-3' ) and the reverse (5' GCCGACAGCAGCAGTTTCATC-3'). The PCR was carried out under the following conditions: $94^{\circ} \mathrm{C}$ for $30 \mathrm{~s}, 60^{\circ} \mathrm{C}$ for $30 \mathrm{~s}, 72^{\circ} \mathrm{C}$ for $60 \mathrm{~s}$, for 30 cycles and finally $72^{\circ} \mathrm{C}$ for $2 \mathrm{~min}$. The amplified products (562 bp) were assayed by electrophoresis in 1.5\% agarose gels. PCR-positive plants were subjected to Southern hybridization analysis[8]. DNA (about 5-10 $\mu \mathrm{g}$ ), was isolated from about 0.1-0.5g leaflets, was digested with XhoI, which recognizes two sites just flanked by hph gene and no other sites in plasmid. Digested DNA were subjected to electrophoresis overnight at $5 \mathrm{~V} / \mathrm{cm}$ on a $0.8 \%$ agarose gel in $1 \times \mathrm{TBE}$ buffer, and then transferred to a nylon membrane by the capillary method. The blot was hybridized with nick translocation ${ }^{32} \mathrm{P}$ labelled XhoI fragments of the hph gene from pCAMBIA-1301. Membranes 
were wrapped in plastic wrap and subjected to autoradiograph for $3-4 \mathrm{~d}$ at $-70^{\circ} \mathrm{C}$.

\section{RESULTS AND DISCUSSION}

Effect of pre-culture, osmosis treatment and hygromycin concentration on transformation

In pre-experiment No. 1, we found the period of pre-culture and osmosis treatment have important effect on transformation based on GUS analysis (Tab 1, Fig 1-a).

The pre-culture process influenced the competence for transformation of bombarded epidermic

Tab 1. Effects of period of pre-culture and osmosis treatment on the average number of GUS blue spots per cotyledon

\begin{tabular}{cccccccc}
\hline $\begin{array}{l}\text { Length ofMedia } \\
\text { cotyledon } \\
(\mathrm{mm})\end{array}$ & \multicolumn{5}{c}{$\begin{array}{c}\text { Period of pre-culture } \\
\text { (d) }\end{array}$} & $\begin{array}{c}3 \text { h osmosis } \\
\text { treatment afterc }\end{array}$ \\
\hline $3 \sim 6$ & D10 & 4.7 & 4.4 & 3.1 & 2.3 & 1.6 & 5.8 \\
& D20 & 4. & 3.5 & 2.3 & 1.9 & 1.3 & 5.3 \\
$7 \sim 10$ & D20 & 6.8 & 7.3 & 6.9 & 5.2 & 4.3 & 8.4 \\
& D40 & 6.3 & 6.6 & 6.4 & 4.6 & 3.8 & 8.2 \\
$11 \sim 13$ & D20 & 5.4 & 6.3 & 6.7 & 4.9 & 3.4 & 9.9 \\
& D40 & 9.4 & 9.1 & 10.4 & 7.4 & 6.2 & 12.2 \\
\hline
\end{tabular}

cells and sub-epidermic cells on the adaxial surface of cotyledons. Tab 1 showed that 1-5 d pre-culture was appropriate and cotyledons with different length had different optimal period in pre-culture.

Serious damage of cotyledons after bombardment was noticed. Since osmosis could alleviate this damage[11], some $3 \mathrm{~d}$ pre-cultured cotyledons were treated for $3 \mathrm{~h}$ in osmosis medium before particle bombardment. Tab 1 also showed that osmotic treatment increased significantly the number of GUS blue spots per cotyledon. The reason for this increase of blue spots is possibly due to that the cells bombarded with gold micro-particles more frequently tended to die without osmosis.

Embryogenesis from cells of cotyledons in different length was repressed by hygromycin (data not shown). In pre-experiment No. 2, cotyledons of $3 \sim 6 \mathrm{~mm}, 7 \sim 10 \mathrm{~mm}, 11 \sim 14 \mathrm{~mm}$ were respectively cultured on selection mediums of D10, D20, D40 containing different concentrations of hygromycin, the percentage of embryogenesis was suppressed respectively by about $50-80 \%$ at 10,15 , $20 \mathrm{mg} / \mathrm{L}$ hygromycin.

Selection of hygromycin resistant calluses and regeneration of hygromycin resistant plants

Cotyledons were cultured in induction medium for $10 \mathrm{~d}$ after bombardment. Cotyledons in different length were transferred onto different solid selection medium containing different concentration of 2, 4-D and hygromycin. Twenty-eight d later, some cotyledons died slowly, and some hygromycin resistant embryogenic calluses could be initiated (Fig 1-b). The surviving embryogenic calluses were transferred into liquid selection medium D10 containing $20 \mathrm{mg} / \mathrm{L}$ hygromycin for weekly subculture. During selection, hygromycin resistant somatic embryos were formed (Fig 1-c). After $6 \mathrm{w}$ of selection, most calluses died slowly and some survived and grew well. These hygromycin resistant calluses (Fig 1-d) were transferred into selection medium (D20) containing $20 \mathrm{mg} / \mathrm{L}$ hygromycin. During further selection, more hygromycin-resistant somatic embryos were formed (Fig 1-e). All hygromycin resistant somatic embryos were subjected to regenerate into hygromycin resistant plantlets (Fig 1-f) using a series of media containing $15 \mathrm{mg} / \mathrm{L}$ hygromycin. The results (Tab 2) showed that on the base of the total number of cotyledons the average number of hygromycin-resistant somatic embryos obtained from one cotyledon was 0 . 3 and the average frequency of resistant plantlets was about $1.6 \%$. The hygromycin-resistant plantlets survived after transplanting to pots in greenhouse.

Analysis of hygromycin-resistant plants

Tab 2. Hygromycin-resistant somatic embryos and plant lets in different experiments

\begin{tabular}{lcccc}
\hline $\begin{array}{l}\text { Exp. } \\
\text { No. }\end{array}$ & $\begin{array}{c}\text { Bomb. } \\
\text { No. }\end{array}$ & $\begin{array}{c}\text { No. of } \\
\text { Cot. }\end{array}$ & $\begin{array}{c}\text { No. of resis- } \\
\text { tant embryos }\end{array}$ & $\begin{array}{c}\text { No. of resis- } \\
\text { tant plants }\end{array}$ \\
\hline 1 & 20 & 112 & 21 & 1 \\
2 & 22 & 131 & 33 & 2 \\
3 & 28 & 184 & 52 & 3 \\
4 & 30 & 201 & 67 & 4 \\
5 & 20 & 125 & 41 & 2 \\
6 & 20 & 130 & 48 & 2 \\
\hline
\end{tabular}

Leaflets of regenerated plants were used for GUS analysis. Leaflets from most tested plants (about 80\%) had GUS activity (Fig 1-g). However, the presence of the gus gene were tested by PCR and leaflets from all tested hygromycin-resistant 


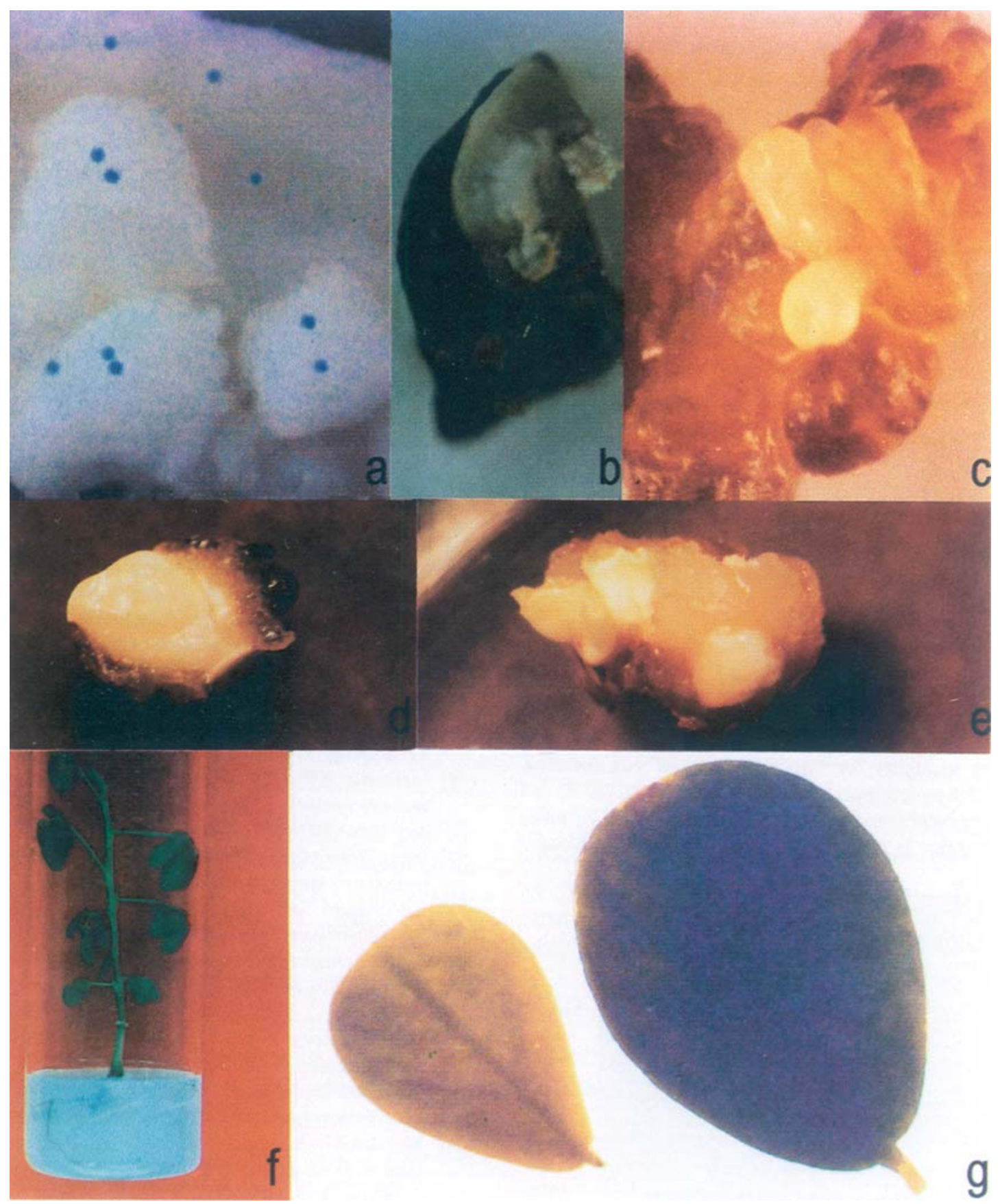

Fig 1. (a) GUS spots on somatic embryos from bombarded cotyledons with pCAMBIA-1301. $\times$ (b) Hygromycin-resistant embryogenic calluses on solid selection medium. $\times($ c) Hygromycin-resistant somatic embryos in liquid selection medium. $\times$ 16 (d) Hygromycin-resistant calluses after liquid selection. $\times 3.5$ (e) Hygromycin resistant somatic embryos developed on resistant calluses. $\times 2.0$ (f) Transgenic peanut plantlet regenerated in selection medium. $\times 0.5$ (g) GUS expression detected on the leave of transgenic peanut plantl (right), but not of non-transformed plant (left). $\times 2.0$

plants were positive (Fig 2). The difference between GUS and PCR analysis may be caused by gene silencing and the possibly chimeric quality of hygromycin resistant plants.
In Southern blot analysis, DNA was isolated from leaflets of 5 hygromycin resistant plants. DNA, digested with XhoI, were subjected to electrophoresis and then transferred to a nylon membrane. The 
blot was hybridized with nick translocation $32 \mathrm{P}$ labelled XhoI fragments of the hph gene from pCAMBIA-1301. The result (Fig 3) showed that the hph gene was integrated into genomes with different copies. Thus, Southern blot confirmed that these hygromycin resistant plants are truly transgenic plants.

In summary, we have successfully obtained transgenic peanut plants through an improved regeneration system[7] via somatic embryogenesis induced by 2, 4-D. As far as we know, this is the first report of the production of transgenic peanut plants

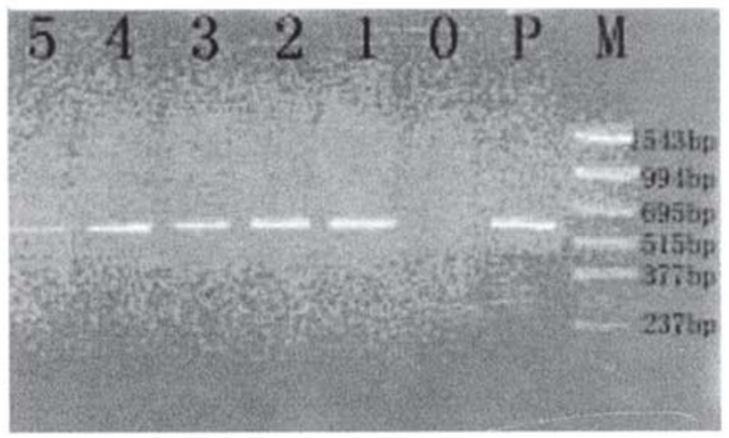

Fig 2. PCR analysis for the presence of gus gene of 5 individual hygromycin resistant plants

M: Molecular weight marker; P: pCAMBIA-1301; 0: nontransformed plant; $1,2,3,4,5$ : hygromycin resistant plants.

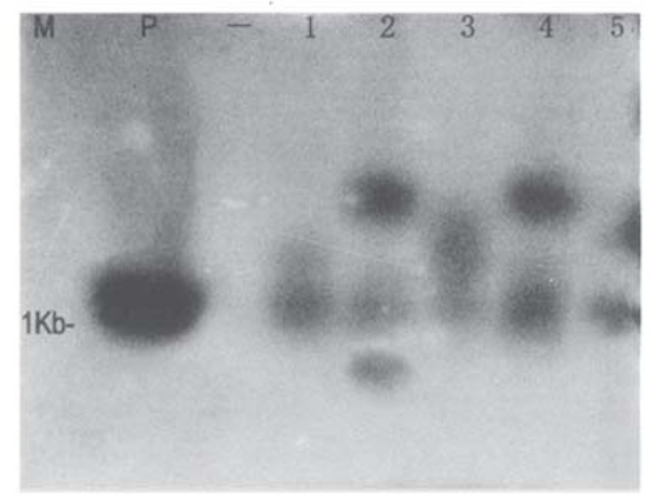

Fig 3. Sothern analysis of 5 individual hygromycin resistant plants M: Molecular weight marker; P: Positive control (pCAMBIA-1301); --: Negative control (non-transformed plant); 1, 2, 3, 4, 5: hygromycin resistant plants. using regeneration systems of the kind.

\section{ACKNOWLEDGMENTS}

Project supported by the National Biotechnology Research Project of 863 High Technology, contract No. 101-01-01-02.

\section{REFERENCES}

[1] Wang A, Fang H, Singsit C, Ozias-Akins P. Transformation of peanut with a soybean vsp B promoter-uidA chimeric gene. I. Optimization of a transformation system and analysis of GUS expression in primary transgenic tissue and plants. Physiol Plant 1998; 102: 38-48.

[2] Cheng M, Jarret RL, Li Z, Xiang A, Demski JW. Production of fertile transgenic peanut (Arachis hypogaea L.) plants using Agrobacterium tumefaciens. Plant Cell Rep 1996; 15:653-58.

[3] Baker CM, Wetzstein HY. Repetitive somatic embryogenesis in peanut cotyledon cultures by continual exposure to 2,4-D. Plant Cell Tissue Organ Culture 1995; 40:249-54.

[4] Chengalrayan K, Sathaye SS, Hazra S. Somatic embryogenesis from mature embryo- derived leaflets of peanut (Arachis hypogaea L.). Plant Cell Rep 1994); 13: 578-81.

[5] Hazra S, Sathaye SS, Mascarenhas AF. Direct somatic embryogenesis in peanut ( Arachis hypogaea L.). Bio Technology 1989; 7:949-51.

[6] Mckently AH. Direct somatic embryogenesis from axes of mature peanut embryos. In vitro Cell Development Biology 1991; 27P:197-200.

[7] Deng Xiang-Yang, Wei Zhi-Ming. Influence of length of immature embryos excised for culture, concentration of 2,4-D light intensity and other factors on somatic embryogenesis and establishment of a high efficiency system of plant regeneration in peanut. Acta Phytophysiologica Sinica 2000; 26:525-31.

[8] Sambrook J, Fritsch EF, Maniatis T. Molecular Clonig: A Laboratory Manual. Cold Spring Harber, NY: Cold Spring Harber Laboratory Press 1989;

[9] Jefferson RA. Assaying chimeric genes in plants: the gus gene fusion system. Plant Mol Bio Rep 1987; 5:387405.

[10] Mettler IJ. A simple and rapid method for minipreparation of DNA from tissue- cultured plant cells. Plant Mol Biol Rep 1987; 5:346-9.

[11] Namdadeva YL, Lup CG, Meyer CS, Devi PS, Potrykus I, Bilang R. Microprojectile- mediated transient and integrative transformation of rice embryogenic suspension cells: effects of osmosis cell conditioning and of the physical configuration of plasmid DNA. Plant Cell Rep 1998; 18:500-4. 